\title{
Communications
}

2020; 8(1): 22-27

http://www.sciencepublishinggroup.com/j/com

doi: 10.11648/j.com.20200801.14

ISSN: 2328-5966 (Print); ISSN: 2328-5923 (Online)

\section{Analysis on Electromagnetic Radiation in Mobile Base Station in Mandalay Region}

\author{
Thae Mar Than ${ }^{1,2}$, Su Su Yi Mon ${ }^{1}$ \\ ${ }^{1}$ Department of Electronic Engineering, Mandalay Technological University, Patheingyi, Mandalay Region, Republic of the Union of \\ Myanmar \\ ${ }^{2}$ Department of Electronic Engineering, Technological University (Hmawbi), Hmawbi, Yangon Region, Republic of the Union of Myanmar
}

Email address:

thaemarthan.mtu@gmail.com (T. M. Than)

\section{To cite this article:}

Thae Mar Than, Su Su Yi Mon. Analysis on Electromagnetic Radiation in Mobile Base Station in Mandalay Region. Communications. Vol. 8, No. 1, 2020, pp. 22-27. doi: 10.11648/j.com.20200801.14

Received: November 11, 2019; Accepted: December 25, 2019; Published: January 23, 2020

\begin{abstract}
The paper presents the analysis on electromagnetic radiation in Mobile Base Station in Mandalay. The electromagnetic radiation effects are critical challenging issue in modern daily life of mobile users. The objective of this work is to investigate whether there is an excess of electromagnetic radiation which can potentially violate the public health safety. The target field is mainly focused on the location of country side and downtown area in Mandalay. The experimental studies for electromagnetic radiation in the specific areas could be confirmed and measured for the actual condition. The experimental studies have been carried out at $40 \mathrm{~m}, 60 \mathrm{~m}, 70 \mathrm{~m}$ and $90 \mathrm{~m}$ for measurement location for downtown site III in Mandalay Region. The outstanding observation for such kind of experimental works was very useful for measuring the radiation in mobile base station in Myanmar. The experimental measurement results have been analysed in this paper. Finally, the safe site from electromagnetic radiation effects could be recommended for people in Mandalay. The analyses confirm that the experimental works could be observed to recommend the usage of mobile devices safely. The confirmation of valuable analyses on electromagnetic radiation in mobile base station would be observed from that experimental works.
\end{abstract}

Keywords: Electromagnetic Radiation, Mobile Base Station, Mandalay Region, Experimental Studies, Numerical Analysis

\section{Introduction}

The exploit of electromagnetic (EM) energy is in the growing movement around the world as wireless communication technologies as well as mobile devices develop into technology service for human beings. The extensive use of cell phones has piloted to cell phone towers (base stations) being positioned in lots of communities. The RF waves fashioned at the base station are emitted into the environment, where people can be uncovered to them. Real measurements of the RF field may be essential to find out whether there is a potential for human experience in surfeit limits [1-6].

Electromagnetic field (EMF) radiation is the surge of photons throughout the space. All photon encloses a definite amount of energy, and the diverse sorts of radiations are characterized by the amount of energy originated in the photons. The electromagnetic spectrum is the variety of all types of EM radiation. The electromagnetic spectrum is shown in Figure 1.

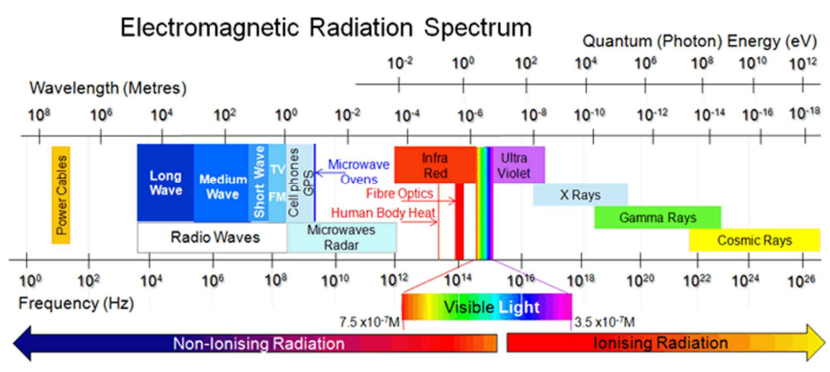

Figure 1. Electromagnetic Spectrum [1].

There are two types of EM radiations: Ionizing radiations (The waves include energy sufficient to prevail over the binding energy of electrons in atoms or molecules, consequently generating ions. e.g. Ultraviolet rays, X-rays, gamma rays and cosmic rays.) and Non-ionizing radiations (The waves do not bear adequate energy per quantum to 
ionize atoms or molecules. e.g. low frequency radiations like radio waves, microwaves, and infrared radiations). The EMF sources are found in many types and Table 1 shows the summary of those sources [7-10].

Table 1. Summary of EMF Sources.

\begin{tabular}{lll}
\hline EMF Sources & Operating Frequency & Transmission Power \\
\hline AM/FM Tower & $540 \mathrm{kHz}-108 \mathrm{MHz}$ & $1 \mathrm{~kW}-30 \mathrm{~kW}$ \\
TV Tower & $48 \mathrm{MHz}-814 \mathrm{MHz}$ & $100-500 \mathrm{~W}$ \\
Wi-Fi & $2.4-2.5 \mathrm{GHz}$ & $10-100 \mathrm{~mW}$ \\
Cell Towers & $800,900,1800,2100,2300$ & $20 \mathrm{~W}$ \\
& $\mathrm{MHz}$ & $1 \mathrm{~W}$ \\
Mobile Phones & GSM-1800/CDMA & $2 \mathrm{~W}$ \\
\hline
\end{tabular}

The EMF radiation in mobile services is principally from two sources: Radiations from base stations and radiation from mobile handsets. Both are at the moderately low end of electromagnetic spectrum. The energy carried is incapable to smash chemical bonds in molecules. They descend underneath the non-ionizing radiation group [11-12].

The research problem to be solved in this paper is to examine the complexity of electromagnetic waves in the working environment. In order to solve that research problem, the experimental studies shall be made the real data in the field areas and analysed on that real measured data. The measurement studies have been mentioned according to the specific location in Mandalay region for the confirmation on safe site for all people.

The rest of the paper is organized as follow. Section II describes the antenna frequency range in cell tower. Section III mentions the analysed parameters for measurement on radiation at cell tower. Section IV expresses the measurement results for experimental studies. Section V discusses on the analysed data and concludes the outcomes of the paper.

\section{Antenna Frequency Range in Cell Tower}

The antennae on cell tower could be transmitted in the frequency range of:

a) $869-890 \mathrm{MHz}$ (for CDMA).

b) $935-960 \mathrm{MHz}$ (for GSM900).

c) $1805-1880 \mathrm{MHz}$ (for GSM1800).

d) $2110-2170 \mathrm{MHz}$ (for $3 \mathrm{G})$.

e) $2300-2400 \mathrm{MHz}$ (for $4 \mathrm{G}$ )*

f) $2400-2500 \mathrm{MHz}$ (for Wi-Fi, Bluetooth).

There are two types of antenna in base station of cell tower. They are rectangular antenna and circular antenna.

\subsection{Rectangular Antenna}

Cell phone tower antennas are regularly sector, or panel antennas. They could direct their energy towards the horizon in a narrow beam, much like a spotlight. Figure 2 shows the rectangular antenna at cell tower in Mandalay Region.

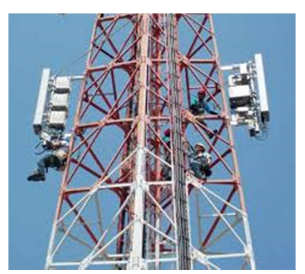

Figure 2. Rectangular Antenna at Cell Tower in Mandalay.

\subsection{Circular Antenna}

Circular Antennas control at microwave frequencies and have point to point (Line of Sight) transmission/reception phenomena. Figure 3 shows the circular antenna at cell tower in Mandalay Region.

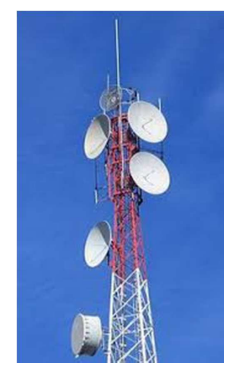

Figure 3. Circular Antenna at Cell Tower in Mandalay.

\section{Analysed Parameters for Measurement}

The analysed parameters for measurement of radiation depend on the radiation pattern and power density. The information on measuring instruments are also described.

\subsection{Radiation Pattern}

In Horizontal Plane, the radiation is maximal in front and reduces in the other route. In vertical plane, the radiation is maximal in major lobe and less in the minor lobe. People could be the places living within 50-300 meter radius are in the high radiation zone.

\subsection{Power Density}

The majority safety limits of radio frequency are defined in terms of the electric and magnetic field strengths over and above in terms of power density. For the lower frequencies, the safety limits are further significantly articulated in terms of electric and magnetic field strength values. At higher frequencies, it is frequently only essential to evaluate the value of power density. In the far field of an RF transmitter power density and field strength are related by standard mathematical equations as given

$$
S=\frac{E^{2}}{377}
$$

where: $\mathrm{S}=$ power density $\left(\mathrm{W} / \mathrm{m}^{2}\right)$

$\mathrm{E}=$ electric field strength $(\mathrm{V} / \mathrm{m})$ 


\subsection{Measuring Instruments}

Broadband omnidirectional antennas $(20 \mathrm{MHz}$ to $6 \mathrm{GHz})$ with portable spectrum analyzer $(6.5 \mathrm{GHz})$ from the Department of Electronic Engineering of Mandalay Technological University (MTU) are used to measure the incident electric field in these experimental studies.
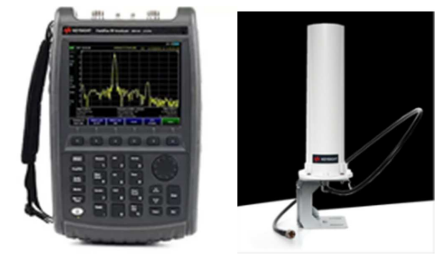

Figure 4. Spectrum Analyzer and Broadband Omnidirectional Antenna.

\section{Experimental Studies}

The experimental studies on radiation measurement in Mandalay region could be expressed in this section.

\subsection{Reference Data}

At first, the GSM frequency bands which were used in Myanmar are given in Table 2.

Table 2. GSM Frequency Bands.

\begin{tabular}{lll}
\hline GSM Band & P-GSM - 900 & DCS - 1800 \\
\hline f (MHz) & 900 & 1800 \\
Uplink (MHz) (mobile to base) & $890-915$ & $1710.2-1784.8$ \\
Downlink (base to mobile) & $935-960$ & $1805.2-1879.8$ \\
Channel numbers & $1-124$ & $512-884$ \\
Equivalent LTE band & 8 (subset) & 3 \\
\hline
\end{tabular}

Table 3 gives the measurement data at $950 \mathrm{MHz}$ for experimental studies in Mandalay Region.

Table 3. $P-G S M-900$.

\begin{tabular}{ll}
\hline \multirow{2}{*}{ ARFCN } & Frequency $(\mathbf{M H z})$ \\
\cline { 2 - 2 } & Downlink \\
\hline 1 & 935.2 \\
2 & 935.4 \\
3 & 935.6 \\
4 & 935.8 \\
5 & 936 \\
6 & 936.2 \\
7 & 936.4 \\
8 & 936.6 \\
9 & 936.8 \\
10 & 937 \\
$\cdot$ & $\cdot$ \\
$\cdot$ & $\cdot$ \\
. & $\cdot$ \\
73 & 949.6 \\
74 & 949.8 \\
75 & 950 \\
76 & 950.2 \\
$\cdot$ & $\cdot$ \\
. & $\cdot$ \\
. &. \\
122 & 959.4 \\
123 & 959.6 \\
124 & 959.8 \\
\hline
\end{tabular}

Table 4 gives the measurement data at $1810 \mathrm{MHz}$ for experimental studies in Mandalay Region.

Table 4. DCS-1800

\begin{tabular}{ll}
\hline \multirow{2}{*}{ ARFCN } & Frequency $(\mathbf{M H z})$ \\
\cline { 2 - 2 } & Downlink \\
\hline 512 & 1805.2 \\
513 & 1805.4 \\
514 & 1805.6 \\
515 & 1805.8 \\
516 & 1806 \\
517 & 1806.2 \\
518 & 1806.4 \\
519 & 1806.6 \\
520 & 1806.8 \\
512 & 1805.2 \\
. & $\cdot$ \\
\hline & $\cdot$ \\
534 & - \\
535 & 1809.6 \\
536 & 1809.8 \\
537 & 1810 \\
\hline & 1810.2 \\
\hline
\end{tabular}

\subsection{Measurement Records}

The measurement records are focused on the specific locations in Mandalay Region. The Measurement Location at $40 \mathrm{~m}$ in the Downtown site III is illustrated in Figure 5. The measurement locations been changed from $40 \mathrm{~m}$ to $60 \mathrm{~m}, 60$ $\mathrm{m}$ to $70 \mathrm{~m}$ and $70 \mathrm{~m}$ to $90 \mathrm{~m}$, respectively.

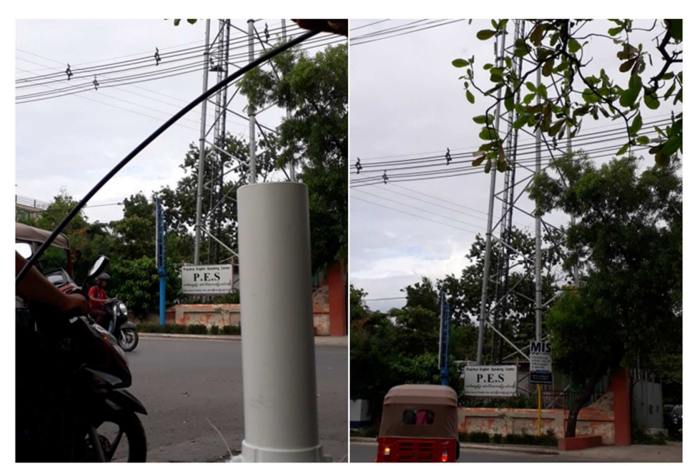

(a)

(b)

Figure 5. Measurement Location at $40 \mathrm{~m}$ in the Downtown Site III.

\section{Experimental Results and Discussions}

The experimental results and discussions on the radiation analysis and power density analysis could be observed in the following section. The analyses on different kinds of location at $40 \mathrm{~m}, 60 \mathrm{~m}, 70 \mathrm{~m}$ and $90 \mathrm{~m}$ for measurement at downtown site III. Figure 6 illustrates the Measurement Results for $950 \mathrm{MHz}$ for $40 \mathrm{~m}$ Location. The channel power is 73.81 $\mathrm{dB} \mu \mathrm{V} / \mathrm{m} / 200 \mathrm{kHz}$ with power spectral density is 20.79 $\mathrm{dB} \mu \mathrm{V} / \mathrm{m} / \mathrm{Hz}$. Figure 7 demonstrates the Measurement Results 
for $1810 \mathrm{MHz}$ for $40 \mathrm{~m}$ Location. The channel power is 89.56 $\mathrm{dB} \mu \mathrm{V} / \mathrm{m} / 200 \mathrm{kHz}$ with power spectral density is 36.55 $\mathrm{dB} \mu \mathrm{V} / \mathrm{m} / \mathrm{Hz}$.

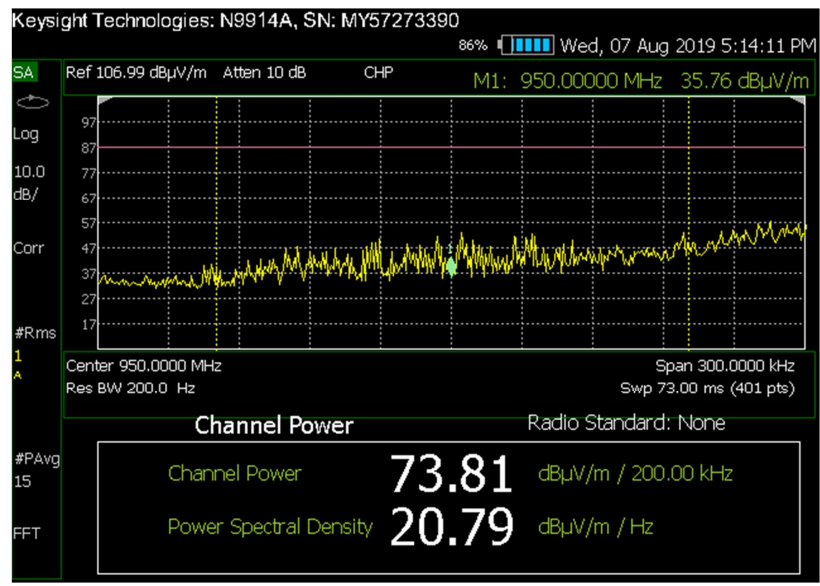

Figure 6. Measurement Results for 950MHz for $40 \mathrm{~m}$ Location.

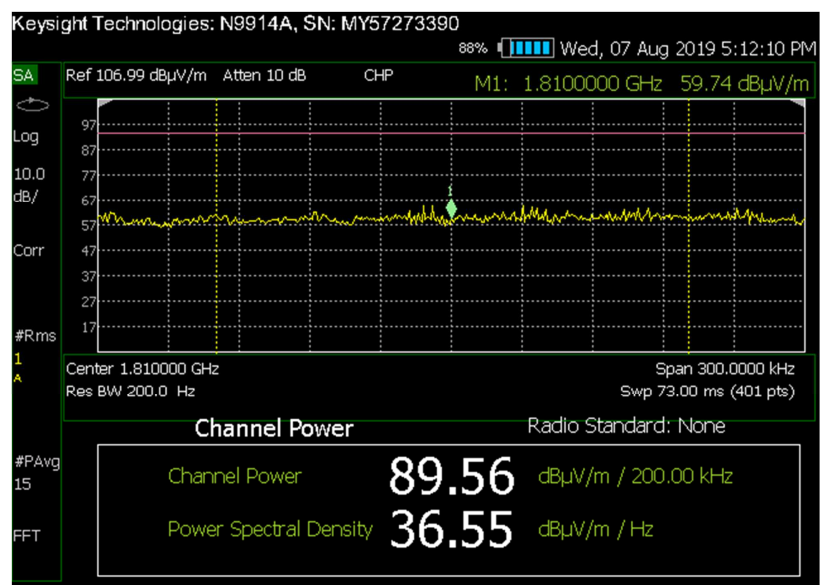

Figure 7. Measurement Results for 1810MHz for $40 \mathrm{~m}$ Location.

Figure 8 illustrates the Measurement Results for $950 \mathrm{MHz}$ for $60 \mathrm{~m}$ Location. The channel power is $64.87 \mathrm{~dB} \mu \mathrm{V} / \mathrm{m} / 200 \mathrm{kHz}$ with power spectral density is $11.86 \mathrm{~dB} \mu \mathrm{V} / \mathrm{m} / \mathrm{Hz}$. Figure 9 demonstrates the Measurement Results for $1810 \mathrm{MHz}$ for $60 \mathrm{~m}$ Location. The channel power is $77.14 \mathrm{~dB} \mu \mathrm{V} / \mathrm{m} / 200 \mathrm{kHz}$ with power spectral density is $24.13 \mathrm{~dB} \mu \mathrm{V} / \mathrm{m} / \mathrm{Hz}$.

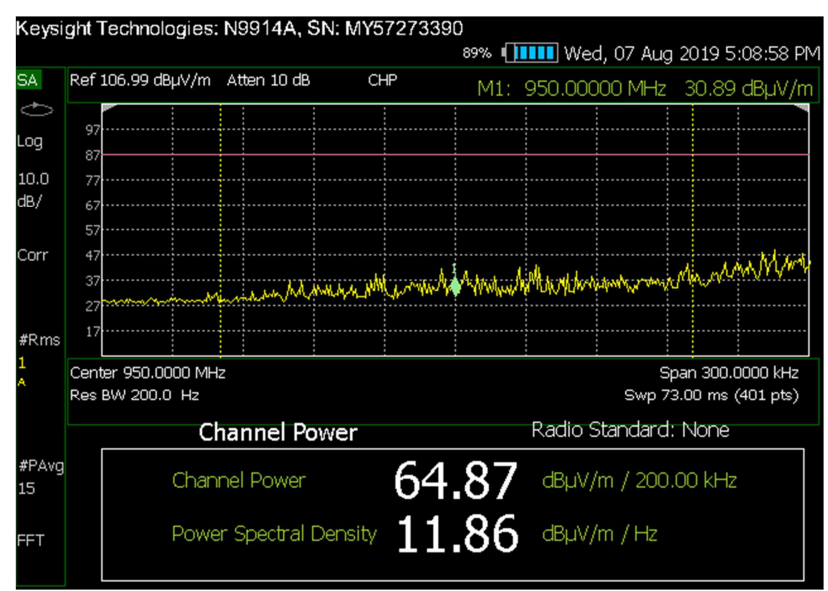

Figure 8. Measurement Results for 950MHz for $60 \mathrm{~m}$ Location.

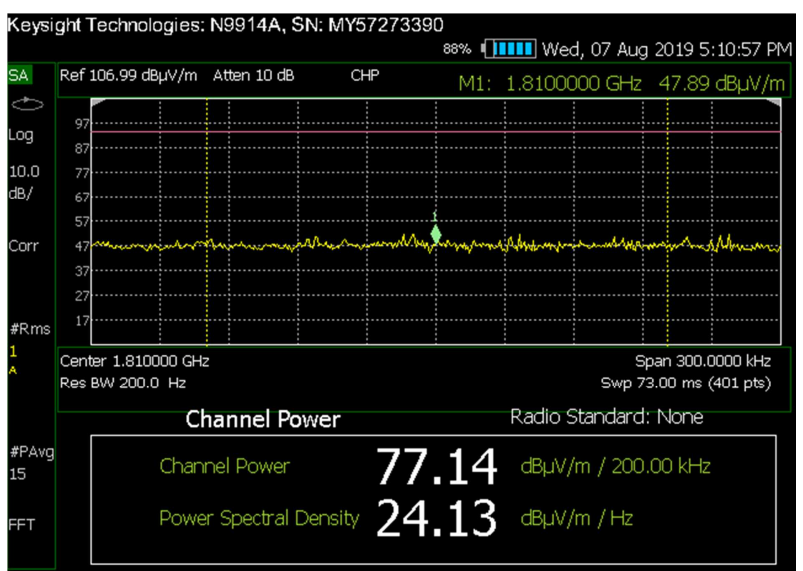

Figure 9. Measurement Results for $1810 \mathrm{MHz}$ for $60 \mathrm{~m}$ Location.

Figure 10 illustrates the Measurement Results for $950 \mathrm{MHz}$ for $70 \mathrm{~m}$ Location. The channel power is 65.57 $\mathrm{dB} \mu \mathrm{V} / \mathrm{m} / 200 \mathrm{kHz}$ with power spectral density is 12.56 $\mathrm{dB} \mu \mathrm{V} / \mathrm{m} / \mathrm{Hz}$. Figure 11 demonstrates the Measurement Results for $1810 \mathrm{MHz}$ for $70 \mathrm{~m}$ Location. The channel power is $76.47 \mathrm{~dB} \mu \mathrm{V} / \mathrm{m} / 200 \mathrm{kHz}$ with power spectral density is $23.46 \mathrm{~dB} \mu \mathrm{V} / \mathrm{m} / \mathrm{Hz}$.

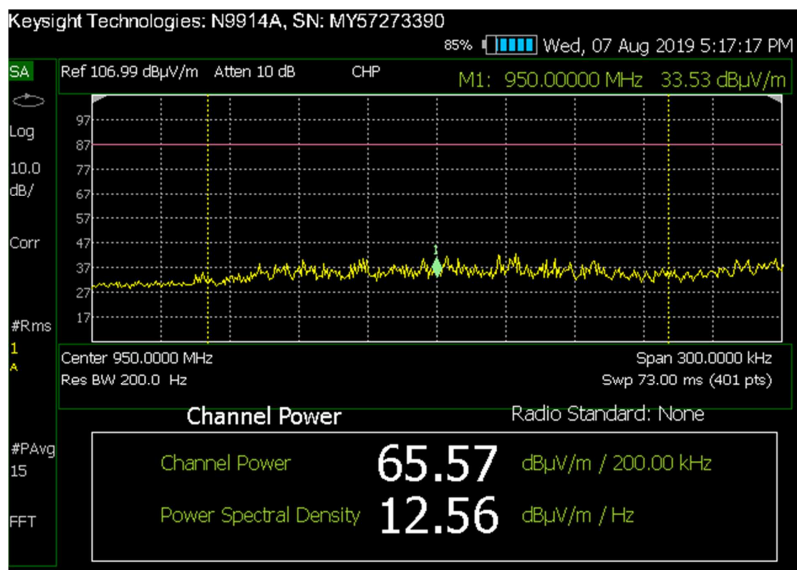

Figure 10. Measurement Results for 950MHz for $70 \mathrm{~m}$ Location.

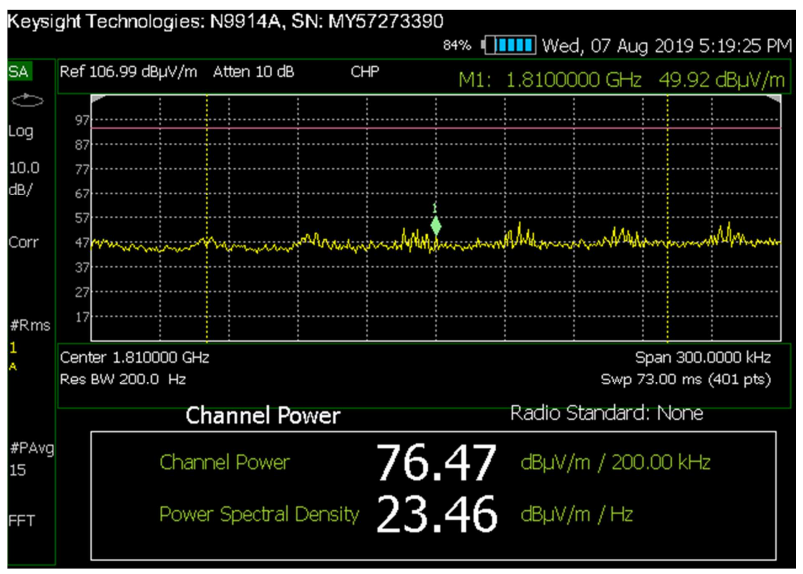

Figure 11. Measurement Results for 1810MHz for $70 \mathrm{~m}$ Location.

Figure 12 illustrates the Measurement Results for $950 \mathrm{MHz}$ for $90 \mathrm{~m}$ Location. The channel power is $71.97 \mathrm{~dB} \mu \mathrm{V} / \mathrm{m} / 200 \mathrm{kHz}$ with power spectral density is $18.96 \mathrm{~dB} \mu \mathrm{V} / \mathrm{m} / \mathrm{Hz}$. Figure 13 
demonstrates the Measurement Results for $1810 \mathrm{MHz}$ for $90 \mathrm{~m}$ Location. The channel power is $86.41 \mathrm{~dB} \mu \mathrm{V} / \mathrm{m} / 200 \mathrm{kHz}$ with power spectral density is $33.40 \mathrm{~dB} \mu \mathrm{V} / \mathrm{m} / \mathrm{Hz}$.

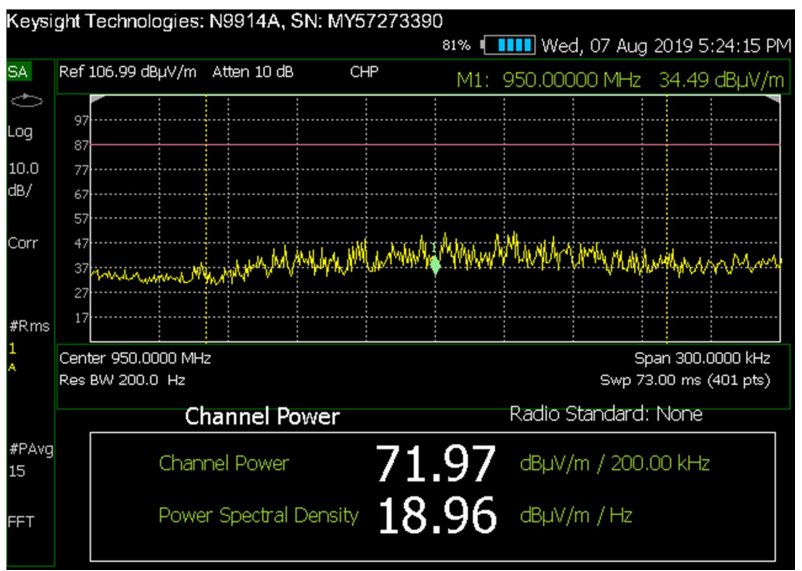

Figure 12. Measurement Results for $950 \mathrm{MHz}$ for $90 \mathrm{~m}$ Location.

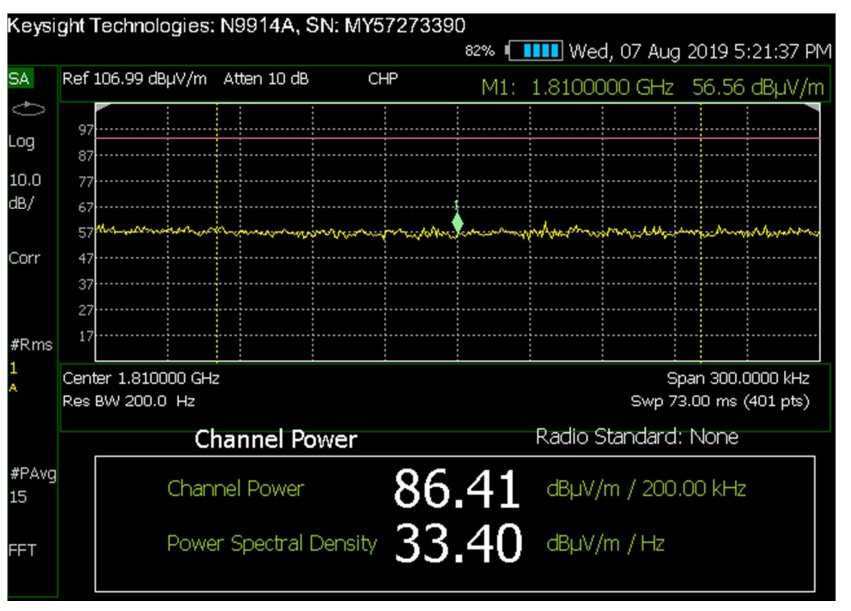

Figure 13. Measurement Results for 1810MHz for $90 \mathrm{~m}$ Location.

Table 5 gives the measurement data for electric fields at two GSM frequencies of $950 \mathrm{MHz}$ and $1810 \mathrm{MHz}$.

Table 5. Measurement Table for Electric Field.

\begin{tabular}{|c|c|c|c|c|c|}
\hline \multicolumn{6}{|l|}{ Electric Field } \\
\hline \multirow{2}{*}{$\begin{array}{l}\text { Distance from Base } \\
\text { Station }\end{array}$} & \multirow{3}{*}{ Measure-ment } & \multicolumn{2}{|c|}{ GSM 900 (935-960 MHz) (measure at $950 \mathrm{MHz})$} & \multicolumn{2}{|c|}{ GSM $1800(1805-1880 \mathrm{MHz})$ (measure at $1810 \mathrm{MHz})$} \\
\hline & & $\mathrm{dB} \mu \mathrm{V} / \mathrm{m}$ & $\mathbf{V} / \mathbf{m}$ & $\mathrm{dB} \mu \mathrm{V} / \mathrm{m}$ & $\mathbf{V} / \mathbf{m}$ \\
\hline $40 \mathrm{~m}$ & & 73.81 & 0.005 & 89.56 & 0.030 \\
\hline \multirow{2}{*}{$60 \mathrm{~m}$} & Right Side & 70.68 & 0.003 & 81.23 & 0.012 \\
\hline & Left Side & 64.87 & 0.002 & 77.14 & 0.007 \\
\hline \multirow{2}{*}{$70 \mathrm{~m}$} & Road & 65.57 & 0.002 & 76.47 & 0.007 \\
\hline & Between Homes & 63.72 & 0.001 & 74.72 & 0.005 \\
\hline \multirow{2}{*}{$90 \mathrm{~m}$} & Road & 71.97 & 0.004 & 86.41 & 0.021 \\
\hline & Between Homes & 62.50 & 0.001 & 78.29 & 0.008 \\
\hline
\end{tabular}

Table 6 gives the measurement data for power densities at two GSM frequencies of $950 \mathrm{MHz}$ and $1810 \mathrm{MHz}$. The analytical analysis on electromagnetic radiation and power density mainly depends on the measurement location in everywhere.

Table 6. Power Density Measurement.

\begin{tabular}{llll}
\hline Power Density $\left(\boldsymbol{\mu W} / \mathbf{m}^{2}\right)$ & & & GSM 1800 (1805- 1880 MHz) \\
\hline Distance from Base Station & Measurement & GSM 900 (935-960 MHz) & 2.396 \\
\hline $40 \mathrm{~m}$ & & 0.066 & 0.382 \\
& Right Side & 0.024 & 0.130 \\
$60 \mathrm{~m}$ & Left Side & 0.010 & 0.130 \\
& Road & 0.011 & 0.066 \\
$70 \mathrm{~m}$ & Between Homes & 0.003 & 1.170 \\
& Road & 0.042 & 0.170 \\
\hline
\end{tabular}

\section{Conclusions}

It was found that the magnitude of electromagnetic field is decreased $60 \%$ (from $40 \mathrm{~m}$ to $70 \mathrm{~m}$ ) when the location is away from the base station according to the measurement data. At 90 $\mathrm{m}$, the measured values are slightly increased because the measured location is straight with the antenna. Buildings, trees and other solid objects may significantly absorb, reflect or scatter the RF signals, so the measured values are slightly decreased. Power density is directly related to the Electric field. So, the resulted values of power density are also decreased when the location is away from the base station according to the results. It is ensure that people who are living around this site are safe from electromagnetic radiation effects. The experimental works in these analyses have confirmed that the specific purposes for safe environment in the real world.

\section{References}

[1] A. Sowa, J. Wiater "Ground potent- ional rise, step and touch voltages during lightning strokes to GSM base station". Electrical Department, Bialystok Technical University, Poland. 
[2] "Lightning Protection \&Grounding Solutions for Communication Sites", Chapter 1, the Lightning "Event".

[3] Slavko Vujevic, Petar Sarajcev and Jakov Petrovic. "TLM Model for the lightning Transient Analysis of the GSM Base Station".

[4] Kizilcay, M.; Hidalen, H. K: "ATP-EMTP Begineerer's Guide for EEUG Members”, European EMTP-ATP Users Group e. V., 2000.

[5] F. P. Dawalibi and C. J. Blattner, Earth Resistivity Measurement interpretation Techniques," IEEE Transactions on Power Apparatus and Systems, Vol. PAS-103, No. 2, February 1984, pp. 374-382.

[6] R. D Southey and W. Ruan "Application of Electromagnetic Field Theory to Measure Correct Grounding System Impedance: A Parametric Analysis "The 15th Conference on Electric Power Supply Industry (CEPSI) Shanghai, China, October 18-22, 2004.

[7] W. Xiong and F. P. Dawalibi, "Transient Performance of Substation Grounding Systems Subjected to Lightning and Similar Surge Currents, "IEEE Transactions on Power Delivery, Vol. 9, No. 3, July 1994, pp. 1413-1420.
[8] IEC 61312-1: 1995 International Standard, Protection against lightning electromagnetic impulse-Part 1: General principles.

[9] L. Grcev and F. P. Dawalibi, "An Electromagnetic Model for Transients in Grounding Systems," IEEE Transactions on Power Delivery, Vol. 5, No. 4, November 1990, pp. 1773-1781.

[10] F. P. Dawalibi, W. Ruan, and S. Fortin, "Lightning Transient Response of Communication Towers and Associated Grounding Networks, "Proceedings of International Conference on Electromagnetic Compatibility, ICEMC' 95KUL, Kuala Lumpur, Malaysia, April 11-13, 1995, pp. 95102.

[11] W. Ruan, S. Fortin, F. P. Dawalibi, and J. Ma, "Computation of Electromagnetic Fields Inside Buildings Located Close to High-Voltage Power Line," Proceedings of the 58th Annual Meeting of the American Power Conference, Vol. 58-I, Chicago, April 9-11, 1996, pp. 276-287.

[12] F. P. Dawalibi and R. D. Southey, "Grounding \& Electromagnetic Interference Analysis and Design - A Complete and Integrated Engineering Solution," Presented at the Southeastern Electric Exchange Engineering and Operations Conference, Bal Harbour, Florida, June 13, 1988. 